\title{
A Renewably Powered Hydrogen Generation and Fueling Station Community Project
}

\author{
Valerie J. Lyons ${ }^{1}$ \\ National Aeronautics and Space Administration, Glenn Research Center, Cleveland, Ohio 44135 \\ Linda S. Sekura ${ }^{2}$ \\ SAIC/Midwest Sustainable Solutions, Maple Heights, Ohio 44137 \\ Paul Prokopius ${ }^{3}$ \\ Hydrogen and Fuel Cell Consultants, Inc., Brecksville, Ohio 44141 \\ Susan Theirl ${ }^{4}$ \\ Ohio Aerospace Institute, Brookpark, Ohio 44142
}

\begin{abstract}
The proposed project goal is to encourage the use of renewable energy and clean fuel technologies for transportation and other applications while generating economic development. This can be done by creating an incubator for collaborators, and creating a manufacturing hub for the energy economy of the future by training both white- and blue-collar workers for the new energy economy. Hydrogen electrolyzer fueling stations could be mass-produced, shipped and installed in collaboration with renewable energy power stations, or installed connected to the grid with renewable power added later.
\end{abstract}

$\begin{array}{lll}\text { CSU } & =\text { Cleveland Station University } \\ \text { GLSC } & =\text { Great Lakes Science Center } \\ G R C & =\text { Glenn Research Center } \\ I P & =\text { intellectual property } \\ \text { NASA } & =\text { National Aeronautics and Space Administration } \\ \text { RTA } & =\text { Regional Transit Authority } \\ U T & =\text { University of Toledo }\end{array}$

\section{Introduction}

\begin{abstract}
$\mathbf{A}_{\mathrm{j}}$
1 Division Chief, Power and In-Space Propulsion Division, 21000 Brookpark Road, MS 301-3, Associate Fellow

2 President/CEO, 20508 Watson Road, non-member

3 President/CEO, 8804 Fitzwater Road., non-member.

4 Program Manager, 22800 Cedar Point Road, non-member.
\end{abstract} team of Ohio nonprofit organizations, universities, industry, the NASA Glenn Research Center, and a transit authority has joined together to propose a project to demonstrate the commercial reality of a renewably-generated-hydrogen fueling station. Hydrogen fuel will be produced by electrolyzing water using an electrolyzer run by wind and solar power - provided by an existing wind turbine and solar panels located at the Great Lakes Science Center (GLSC) in downtown Cleveland, Ohio. The construction of a renewably-generated-hydrogen fueling station will become a template to be replicated for commercialization and economic development. The intellectual property (IP) generated is planned to be held in a trust for the citizens of Ohio. NASA has a long history of working with hydrogen fuel and fuel cells. ${ }^{1}$ Engineers at the NASA Glenn Research Center will use their experience in electrolyzer and fuel cell technology and in handling hydrogen fuel to advise the team. ${ }^{2}$ Cleveland State University's (CSU) Nance College of Business will create a template for station replication and tools for commercialization and marketing. The University of Toledo (UT) will conduct research and development to improve the efficiency of the electrolyzer and

American Institute of Aeronautics and Astronautics 
improve its commercial potential. These university staff and students will have hands-on exposure to zero-emissions hydrogen production and fuel-cell-powered transportation technology.

The Greater Cleveland Regional Transit Authority (RTA) will demonstrate the commercial reality of fueling a fuel cell RTA bus with renewably-generated hydrogen as it runs in revenue service on a regular route. A commercialization template will be developed and replicated in other Ohio cities (and elsewhere), generating a green manufacturing supply chain. Industry will manufacture and market additional hydrogen fueling stations. Green jobs will be provided as the project is accomplished. For the prototype station, planned for construction at the GLSC, hydrogen will be stored on-site and will be used in hydrogen fuel cell vehicles that include a city bus in revenue service, and potentially forklifts, utility vehicles, fuel cell cars, and service equipment supporting the Cleveland-Cuyahoga County Port Authority, the Cleveland Browns Stadium and other organizations on Lake Erie. Marketing will be enhanced by the visibility of the location on Ohio's North Coast, currently drawing millions of visitors annually to the GLSC, the Rock and Roll Hall of Fame and Museum, the Cleveland Browns Stadium, and Burke Lakefront Airport; and through the use of a revenue-service fuel cell bus. The station will be unique: commercial-sized renewably powered hydrogen generation and fueling station housing a high-capacity single-stack electrolyzer.

\section{Background and History}

The vision which generated the proposed demonstration project is "commercialization of renewably-generated hydrogen fueling stations for sustained economic development". The proposed project would demonstrate renewably-powered hydrogen generation technology in order to create a market, which would create jobs and lead to further economic development through the use of readily available, locally-produced hydrogen fuel and through the development of a new infrastructure of renewably-powered hydrogen fueling stations across the country (and eventually around the world). One unique element of this project is the teaming arrangement between private and public entities, producing benefits to all parties. The plan is for the intellectual property generated by the team to become the property of a "public trust" so that anyone can access this "open source" for their own use to construct a station or to set up businesses for station construction or other services and manufacturing related to hydrogen fueling stations.

The project would validate the commercial viability of a renewably-powered hydrogen production and zero-emissions hydrogen fueling station through demonstrating:

1) A low cost stack in a high-capacity electrolyzer - planned as a future commercial product.

2) Electronic control unit enabling connection to variable renewable power sources and/or grid connection.

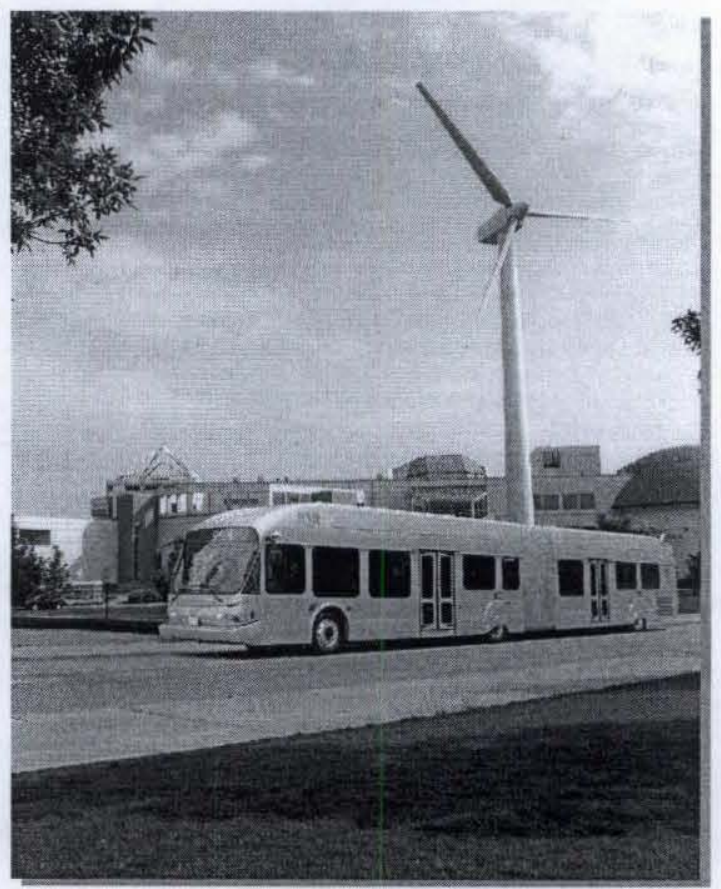

Figure 1. Artist Concept of a Fuel Cell Bus in Front of the Great Lakes Science Center

3) A renewably-generated-hydrogen (zero-emission) fueling station that is cost competitive with natural gas (fossil fuel) stations.

4) Independence and flexibility: Enabling remote, standalone power - requiring only wind and/or solar power and water benefitting farmers, military, remote settlements.

5) Reduced emissions: The hydrogen fuel source is local water (removing dependence on imported oil) and the tailpipe emissions are only water vapor, providing cleaner air and keeping the water resource in the same region.

6) Water-use neutral: Recombining the hydrogen with oxygen from the air in a fuel cell to generate power recovers the water used in the electrolysis process.

7) Portability: The planned fueling station will be an easily transportable package which, along with its ability to use renewable power, allows the station to be easily relocated.

8) Capability as a storage medium for renewable power: Wind farms and solar power stations could install an electrolyzer system and generate hydrogen (and oxygen) to sell as valuable by-products of their excess energy. These products could also be coupled with fuel cell power systems to generate power during low wind and solar conditions. 
The project's objectives are to create market pull by quickly (within 18 months to 2 years) demonstrating the commercial reality of a renewably-generated hydrogen fueling station. There are already interested end users, and as more are identified, market pull is generated and leads to the need to generate more fueling stations and the need to create a mass-production capability to meet consumer demand and reduce cost per unit.

The project plan will leverage this "disruptive" technology for economic development by placing the IP in a public trust. Cleveland State University's Nance College of Business (CSU) is creating a template for station replication and tools for commercialization planning and an economic development potential workplan. As the commercialization template is developed by CSU's Nance Business College and replicated in other communities, this collaborative effort will enable establishment of a green manufacturing supply chain. Also, this project will provide university staff and students with hands-on exposure to zeroemissions hydrogen production and fuel cell transportation technology to expand clean energy technology knowledge and research, resulting in "green" expertise and jobs for our current and future workforce,

\section{Economic and Environmental Needs and Response}

A design and engineering team comprised of the NASA Glenn Research Center (GRC), technical advisors under contract to The Ohio Aerospace Institute (OAI), and a fabrication team from Sierra Lobo, Inc. (SLI) will build an electrolysis-based hydrogen fueling station with circuitry to enable the use of renewable power sources. The hydrogen will be used as the fuel for a proton exchange membrane (PEM) fuel-cell-powered bus. In parallel with the design and construction of the electrolyzer, the engineering college at the University of Toledo will perform research and development to improve the operating efficiency of the nextgeneration commercial electrolyzer. This work will be conducted in collaboration with the NASA Glenn researchers currently working to improve the efficiency of space-based electrolyzers with the expected result being a spin-off benefit to both efforts. To demonstrate adaptability to a commercial, public scenario, the station will be built on the grounds of the Great Lakes Science Center (GLSC) on the shore of Lake Erie in downtown Cleveland, Ohio, near Browns Stadium and the Rock and Roll Hall of Fame and Museum where it will be visible to millions of visitors annually.

The station will be designed with the safety and ergonomic characteristics that will allow it to serve as a template that could be replicated at any commercial, public location at which a traditional fueling station would be permitted. The Intellectual Property (IP) that is developed as a result of this project will be held in a public trust for the citizens of Ohio, with access to these blueprints for any individual or entity. In this way, green companies and green jobs may flourish anywhere in the nation, as the clean energy economy expands. These new or existing companies that utilize the templates will, for the most part, require assistance by the initial design team for guidance, consulting, parts, and expertise in manufacturing the systems. Companies that wish to manufacture a station or set up shop to build and distribute stations will benefit from site visits to the Cleveland hydrogen fueling station and the companies that can provide products and services.

The design will be weather-proofed for Cleveland's wide-ranging weather conditions and a portico canopy will provide partial cover from the elements for the station and for those fueling vehicles from the station. The oxygen generated by the electrolyzer will be vented in this initial station design, but there is an opportunity for future commercialization of this high purity, medicalgrade oxygen product. The station built under this project will include the permitting and siting as a permanent installation. However, a design option will be developed to allow the station to be configured for portability. To give the station the flexibility to be powered directly from renewable wind and solar power systems, electrical interface hardware and controls will be developed to enable the station to be powered from the existing GLSC wind and solar power systems. Once the station is complete, a hydrogen fuel cell bus will be operated by the Greater Cleveland Regional Transit Authority (RTA) in revenue service on a daily route, fueling it twice per day.

Cleveland State University's Nance College of Business (CSU) will continue to conduct market research as the station is being built, and to work alongside SLI, NASA, and others as the station is built, in order to develop a template for duplication, with the goal of developing a green manufacturing supply chain, along with retraining workers for green jobs. CSU will also search for early market opportunities such as capturing and selling the oxygen generated as a byproduct of the fueling station's electrolyzer operation. CSU will begin by developing commercialization and marketing plans. After the implementation of the initial fueling station, CSU will continue to collect information to expand the economic development planning, outreach, and implementation, and to provide information for reporting to funders. 
Outreach will also be accomplished by the Great Lakes Science Center, as they plan an exhibit about fuel cells, the hydrogen economy, and the fueling station. The GLSC will also work with the Greater Cleveland Regional Transit Authority (RTA) to provide additional educational displays and other information on the fuel cell bus.

\section{Technical and Programmatic Approach}

\section{A. Electrolyzer}

The electrolyzer will be provided to the project by Proton Energy Systems, one of the team's industrial partners. The electrolyzer is a new design based on a commercialized version of a high capacity military electrolysis stack. The uniqueness of this unit will be its capacity to generate $21 \mathrm{~kg}$ of hydrogen per day using a single, 65-cell, proton exchange membrane (PEM) electrolysis stack and up to $63 \mathrm{~kg}$ /day with three stacks ganged together in a single electrolysis unit.

The hydrogen will be generated at a pressure of $800 \mathrm{psi}$, more than 3 times higher than a currently available commercial PEM electrolyzer. This is significant when utilizing an electrolyzer in a hydrogen fueling station since a higher generation pressure reduces the size of the downstream hydrogen compressor as well as the energy required to compress the hydrogen up to the required 6,000-7,000 psi fueling pressure. This can represent a twofold benefit in developing a commercial fueling station. It can be manifest as a lower station capital cost since a lower cost compressor would be required and the station's parasitic power would be reduced. In addition to the electrolyzer being built and provided to this task, the preliminary design of the hydrogen fueling station itself will be undertaken and will include a site layout of the equipment, electricity and water consumption estimates, and hydrogen and oxygen production estimates. Completion of the hydrogen fueling station preliminary design will be followed by a detailed station design in step 2 and then station permitting activities will be addressed.

\section{B. Building the Station}

The objective of this effort will be to complete detailed design, build and demonstrate the technical and commercial viability of a high capacity, electrolysis-based hydrogen fueling station. This station will be designed around the electrolyzer provided in step 1 and will serve as the baseline template of a station to be marketed nationwide. This station's generation capacity will be limited by the capacity of the electrolyzer built in step 1 , which can be as much as $63 \mathrm{~kg} / \mathrm{day}$. However, since electrochemical systems are modular, the station's capacity could be increased by simply adding electrolysis units and hydrogen storage capacity. The design developed for this station will define options for expansion. The design will be a generic design that could be replicated at any public or private site. In keeping with this characteristic, water treatment hardware will be identified that will allow the station to accept normal city water as a water source. Also, a transportable station configuration will be designed. For further flexibility, the design will include the capability of the station to be powered directly from the power grid or off-grid from stand alone wind and solar renewable power systems. Both of these options will be demonstrated in the operation and demonstration phase of this effort at the station installation site at the Great Lakes Science Center (GLSC). All the safety protocols for hydrogen stations (oxygen venting, etc.), already standardized in states such as California, will be incorporated in the station design and will become part of the permitting process.

Aside from the electrolyzer, the other station key components are a buffer tank to collect the hydrogen generated by the electrolyzer, a compressor to take the hydrogen from the buffer tank up to its final storage pressure $(6,000-7,000 \mathrm{psi})$, high pressure tank to store the hydrogen fuel, and a standardized dispenser to dispense the hydrogen into the fuel cell bus or other designated fuel cell vehicles. All the components will be installed in weather-proof enclosures except for the storage tanks and the dispenser, which is built as a weather-proof device. For the initial station, the general public will not have direct access to any of the station components, even though they will be displayed at the GLSC grounds and operated in full public view. The storage tanks will be set in the background, well away from public access, the hydrogen processing components will be fenced and accessed only by trained maintenance technicians, and the dispenser will be gated to allow access to only trained operators. A lighted canopy will cover the dispenser to shield the operator from the elements.

\section{Commercialization Considerations}

Renewably-generated-hydrogen fueling stations face several primary barriers to commercialization: relatively high capital cost, public perception that hydrogen is unsafe, and widespread perception of the hydrogen economy as expensive and too far in the future due to a lack of infrastructure and time to build it. For the proposed project, the Great Lakes Science Center will educate the public on the technology and the use of hydrogen fuel and fuel cells. They will create educational signage for the fueling station, aid in the design of the installed station to make it more compelling and attractive, and provide space for the station on their property. As for the technology aspect of the project, the electrolyzer and station will be used in daily revenue service on a regular route for a major transit authority. Proof of concept for hydrogen fueling stations in general has already been achieved, but this 
much-needed enhancement to the technology (locally produced, clean, renewably produced) will greatly enhance the public's perception of the viability of the hydrogen economy and its readiness today, versus far in the future. Putting the station to use daily at a highly visible public site will provide evidence that a high-capacity renewably-generated-hydrogen station meets the performance requirements and shows its ease of use.

The GLSC will provide renewable power via their existing wind and solar power systems.

\section{Operation and Maintenance of the Station}

To demonstrate its viability and utility, the station will be operated daily to fuel a fuel-cell-powered transit bus. The bus will be fueled once or twice daily as part of the regular revenue route the Greater Cleveland RTA establishes for the bus. The fueling operations, each of which will take approximately 5-10 minutes, will serve two purposes. First, hands-on operating data will be obtained which will be invaluable in developing a commercial market for the station. Secondly the public will witness the fueling operation to gain familiarity with hydrogen and help dispel the fear of handling it as a transportation fuel.

The Greater Cleveland RTA will provide a driver, maintain and house the bus, determine and advertise the route and collect revenue. Through revenue service operation, the instrumented fuel cell bus will provide the operational and experimental data base to identify and guide additional technology improvements and design modifications that will enable a commercially viable fuel cell vehicle specific to the bus rapid transit market. Commercial possibilities include establishing bus manufacturing companies to fulfill the demand for clean transit vehicles.

\section{E. Commercialization Challenges}

Fuel cell buses (and other fuel cell vehicles) face two primary barriers to commercialization: relatively high capital cost of fuel cell and hybrid systems, and lower durability relative to diesel engines. The most effective path to address these barriers includes design improvement and technology development. This project focuses on these commercialization barriers by expanding the hydrogen infrastructure and providing public visibility to a zero-emission clean fuel that has the potential to be less expensive than petroleum fuel. Due to limitations in the physical capabilities of materials used in batteries, they most likely will not be able to safely provide charging for distances longer than 30-40 miles, and in very expensive prototypes have demonstrated only a little over 100 miles on a charge. Conventional biofuels require large land areas and large amounts of water and require complex chemical processes to produce liquid fuel. It is better to use the water directly for fuel. Also, in cold climates with short growing seasons, biofuels must be supplemented with other fuels - usually fossil fuels. As more people see that hydrogen is the best answer for zero-emission daily fuel use, and as the infrastructure expands, demand will increase, enabling an increase in research to increase durability of fuel cell vehicles. Fuel cells and fuel cell vehicles will be improved. The obstacle to technological improvement is not in physical limitations, but in funding and research.

\section{Capitalizing on Renewable Energy Technology}

Fueling stations which produce hydrogen from reformed fossil fuels have been in place for years. The demand for even these nonsustainable systems is great due to the increasing desire for zero-emission vehicles. So the demand for zero-emission fuels along with zero-emission fuel generation is more compelling. It will match the cost of the non-sustainable systems, even at this earlymarket entry phase, when utilizing life-cycle costing and/or life-cycle assessment. There is a lot of interest in the use of hydrogen fuel, especially when generated renewably. In a natural-gas-reforming station process, natural gas is purchased from a supplier, and then put through a reformer. The reformer burns natural gas to run the process. The rest is waste - mostly $\mathrm{CO}_{2}$. Then it is liquefied, which purifies the gas. Also, a natural gas turnkey system has no capability to use renewables to power the system. And this assessment of natural gas systems versus water-electrolyzer systems does not include the numerous environmental and biodiversity (and resultant economic) impacts related to extraction and distribution of natural gas versus the simple acquisition of local freshwater. Initial costs of the natural gas system and the electrolyzer system are similar considering overhead, profit margin, and labor costs. But that comparison is before considering mass production. Even if 10 or fewer hydrogen stations are built, their cost would still be comparable to a turnkey natural gas station's cost, which is being mass produced at a rate of 300-500 at a time. As more renewably-generated-hydrogen stations are built, the cost will gradually decrease. The project will provide a low cost high-capacity electrolyzer, which will produce hydrogen inexpensively even if powered by the standard grid (which can be less expensive than current gasoline prices), but will be much less expensive when using renewable power.

The intellectual property (IP) that is developed as a result of this project will be held in a public trust for the citizens of Ohio. The IP trust would be self-funding. The intent is to have a limited license (e.g., a royalty-free license to make, use and sell any IP which is funded by this project may be limited to Ohio) to be contributed into a revolving community technology insertion fund 
for reinvestment into other advanced energy commercialization projects. The purposes for the fund are to 1) make sure all of the institutions and for-profit businesses place value on being part of a community initiative which they could not accomplish by themselves, and 2) attempt to "anchor" the investments (time and money) in Ohio, integrating it with local economic development, so it is difficult for it to "walk away" after the funding stages are over.

How self-funding is generated under this "royalty-free" license is that a "social contract" would be signed by those seeking to profit from the IP, with a percentage (to be negotiated) of any revenues obtained being donated as a charitable contribution in the community. This donation would take the form of either an amount into the Trust or an equivalent investment into the community expanding advanced energy. If the company is outside of Ohio, the royalties would be negotiated.

\section{A. Demand for Stations and Spin-off Technologies}

There are already interested end users for the station, and for the hydrogen produced, with potential markets in rural and urban communities, vehicle fleets, warehouses (for using hydrogen lift trucks in their facilities), wind farms (for energy storage), businesses and industries in industrial park settings, etc.

The Port of Cleveland is seeking to be a cutting edge sustainable Port. They recently hired a dedicated sustainability manager and are focused on greening the existing Port operations. The City of Cleveland has a master plan that includes green areas and sustainable neighborhoods in the area adjacent to the GLSC. The Port Authority has many vehicles that can potentially be converted to hydrogen fuel: gators, work trucks, forklifts, utility (golf) carts, in addition to boats, ships, and ferries which can use hydrogen-enriched fuel.

Other potential users in the Cleveland area are the Cleveland State University trucks and vans, the Burke Lakefront Airport service trucks, the Cleveland Browns Stadium ground maintenance vehicles, the Rock ' $n$ Roll Hall of Fame and the GLSC's SS Mather museum ship portable power systems, Detroit prototype fuel-cell cars which may be visiting in the area, or traveling through, for demonstrations.

Another important application is for energy storage of renewable power. Wind farms could install an inexpensive low-capacity electrolyzer system and produce hydrogen for later use during high wind periods. Wind farms could also use or sell the hydrogen (and the oxygen) produced.

\section{B. Business Plan}

The Cleveland State University's Nance College of Business will create an economic development work plan tool to determine objectives and metrics for building a "Hydrogen Economy" (with an eye toward a larger "clean energy economic development" effort and sustainable business practices). They will identify and evaluate obstacles and incentives and identify stakeholder sectors which could comprise supply chain (components, etc.) and infrastructure capacity. Nance will assess and identify skills and types of jobs required in a hydrogen economy and develop training programs to grow such a workforce. The main goal is a new model for public development related to these products and services, catalyzing new businesses and new jobs.

Cleveland State University's Nance College of Business has begun developing a "Hydrogen Energy Roadmap" that will help to establish a better understanding of the potential use of hydrogen as an economic driver in Ohio. To this end, the Nance College of Business is working in tandem with the development of the renewably-generated-hydrogen fueling station to continue assessing and defining the supporting and inhibiting factors that will frame and shape the future of a hydrogen economy in Ohio. Nance will continue to develop a public awareness campaign that will educate the general public and government and private decision makers about the potential benefits of the use of hydrogen in Ohio, and showing that a hydrogen-based economy is ready "now" and not a concept far in the future. Following the completion of the first renewably-generated-hydrogen fueling station, the Nance College of Business in collaboration with project partners will begin developing a model for private-sector-led partnerships involving public funds, with the public and private sectors working together to fully develop and implement hydrogen's potential, to produce and deliver hydrogen in an affordable and safe manner, and to identify end-use energy applications for hydrogen in Ohio. Activities will include creating a portfolio of business programs and services to support the commercialization of hydrogen applications across various industry sectors. 


\section{Conclusion}

There is a lot of interest in the possibility of purchasing a renewably-generated-hydrogen fueling station for a wide range of applications. Vehicles and equipment with internal combustion engines (ICE's) can utilize the hydrogen fuel once the engines are retrofitted. Fuel-cell powered vehicles can use the hydrogen fuel three times as efficiently as ICE's. This clean hydrogen fuel may also be used in a fuel cell back-up power system using the stored hydrogen produced when there is an excess of wind or solar energy in the event of a grid power failure.

Producing hydrogen fuel from local tap water will save money and provide regional energy independence from reliance on petroleum supplies from outside of the U.S. Air quality will improve as the use of hydrogen fuel increases, reducing compliance issues, paperwork, health problems, and the costs associated with these. These benefits are provided when using standard grid power (of any kind). But the proposed station is unique in that it will be a commercial-sized high-capacity low-capital-cost station that can run on either grid power and/or renewable power. When renewable sources provide the electricity to the station, (such as wind or solar), all of these benefits increase since the complete fueling process will be zero-emission (except water vapor). This process is clean from fuel acquisition and production through to the tailpipe - and, after a short payback period for renewable power capital costs, will exponentially reduce fuel costs.

This renewably-generated hydrogen fueling station project will expand the clean hydrogen economy, enable many other clean energy technologies, businesses, and jobs, will save money and be environmentally responsible, and enhance sustainable economic development.

\section{References}

${ }^{1}$ Scott, J. H., “NASA's Fuel Cell Contributions," IECEC, AIAA-2008-5793, July 2008.

${ }^{2}$ Colozza, A., and Prokopius, K. "Hydrogen Generation through Renewable Energy Sources at the NASA Glenn Research Center," NASA CR-2007-214682, April 2007. 